Michalina PUCEK

\title{
CASES OF WHITE SPOTTING IN SHREWS
}

\author{
PRZYPADKI CZESCIOWEGO ALBINIZMU U RYJOWKI
}

Albinism is rather a rare phenomenon in shrews. Specimen 3 of complete albino shrews have been described by Sélys-Long s hamps (1839), Ja ckson (1928), C a brera (1932), A 11 en (1935), Hamilton (1939), Murray (1939), Sime (1940), Ulmer (1940 a, b), Shapiro (1950), V a n Gelder (1959), Elder (1960), Dexter (1961), Jones (1962), and Will i a m s (1962).

Cases of white spotting in shrews are rare as well. A number of notes on this subject can be found in literature. As early XIX century Sélys-Long$\mathrm{sch}$ am ps (1839) and $\mathrm{H}$ e r o n-R o y e r (1883) described some partly white shrews. Similarly coloured specimens were recorded by other more recent authors (Mohr, 1931, Pearce, 1934, H a m i 1 to n, 1939, Heptne r, 1939, Christian, 1947, Findley, 1955, H a r r ison, 1957, Van Bree et al., 1963, S a in t Girons, 1963).

The observations of these authors, reporting both complete albinism and white spotting in shrews, include the following species: Sorex cinereus (K e r r, 1792), Sorex tundrensis $(=S$. caecutiens $\mathrm{L}$ axm a n $\mathrm{n}, 1788), S$. vagrans $\mathrm{B}$ a i $\mathrm{r} d, 1858$. S. araneus $\mathrm{L}$ innaeus, 1758, Neomys fodiens ( $\mathrm{P}$ e n a n t, 1771), Blarina brevicauda (S a y, 1823), Cryptotis parva (S a y, 1823), Crocidura suaveolens (P a 11 as, 1811), C. russula (H e rma n n, 1780), C. leucodon ( $\mathrm{H}$ e r m a n n, 1780), and C. schweitzeri P e t e r s.

It will be seen from this list that no such anomalies in coloration have hitherto been observed in $S$. minutus, which may be due to the rare occurrence of this species.

In the collection of the Mammals Research Institute of the Polish Academy of Sciences at Białowieża there is a specimen of Sorex minutus L in na e us, 1766, with a large white spot, about $2.0 \times 1.5 \mathrm{~cm}$, on the belly, white forefeet and the top of the tail. This specimen (Coll. No 39084) was caught in the Wierzchlas yew reserve (Bory Tucholskie, $\varphi=53^{\circ} 31^{\prime}, \lambda=18^{\circ} 08^{\prime}$ ), as one out of 93 specimens of $S$. minutus. It was a juvenile female, weighing $2.7 \mathrm{gms}$, its body length was $54.6 \mathrm{~mm}$, tail length $37.6 \mathrm{~mm}$, and hindfoot length $10.8 \mathrm{~mm}$. The specimen is kept in the form of a flat skin and a carcass preserved in alcohol. The shrew was trapped in a metal cone together with another specimen and was bitten in the region of head. This made the determination of the colour of its eyes impossible. However it is most likely the anomaly known as white spotting.

In addition, in three young males of $S$, araneus Lin na e us, 1758 (Coll. Nos $29560,37671,38034)$ tufts of white hair or small white spots were observed on the ears. One of them was caught in North-Eastern Poland on July 11, 1962, the other two were collected in the Swiętokrzyskie Mts. $\left(\varphi=50^{\circ} 55^{\prime}, \lambda=20^{\circ} 53^{\prime}\right)$ in August and September 1963. These three cases were found among $1090 \mathrm{spec}-$ imens of $S$. araneus examined.

Among 4053 shrews ( $S$. araneus) from the Białowieża Forest there was one with a white spot, about $0.5 \mathrm{sq}$. $\mathrm{cm}$ in area, extending from the left ear to the forehead, as well as a tuft of white hair behind the right ear. It was a female (Coll, No 3512) caught on June 9, 1948. 
The occurrence of white spots in the region of head in shrews is known from many records. Crowcroft (1957) associates them with the growth of new hair where it was plucked during copulation. These spots were observed in sexually active females, and such cases are not regarded as white spotting. On the other hand, there are no grounds to refrain from speaking about white spotting in the case of such spots in sexually inactive young animals, especially in males. In order to carry out an exhaustive analysis of this anomaly it is necessary to collect still more specimens.

\section{REFERENCES}

Allen G. M., 1935: An albino shrew. J. Mamm., 16: 223. B ree, P. I. H. van, Chanudet F. \& Saint-Girons M. C., 1963: Notes sur des colorations ches les Musaraignes (Insectivora, Soricidae). Mammalia, 27: 300-305. Cabrera A., 1932: Los mammiferos de Marruccos. Madrid, pp. 1-361. Christian J. J., 1947: Note on light colored Blarina. J. Mamm., 28: 403. C r o wcroft P., 1957: The life of shrews. Max Reinhardt: 1-166. London. Dexter R. W., 1961: An albino shrew from Ohio. J. Mamm., 42: 96. Elde r W. H., 1960: An albino Cryptotis from Missouri. J. Mamm., 41: 506-507. F indle y J. S., 1955: Possible himalayan color pattern in the masked shrew. Ib., 37: 257 Gelder R. G., van, 1959: An albino Sorex vagrans. Ib., 40: 438. H a m il t o n W. J. jr., 1939: Albino Blarinas. Ib., 20: 252. H a r ris on, D. L., 1957: A remarkable pied Common shrew (Sorex araneus L in n.). Naturalist, Lond., 862: 92. Heptner, V. G., 1939: The turkestan desert shrew, its biology and adaptive peculliarities. J. Mamm., 20: 139-149. H e r o n - R o y e r, M., 1883: Cas d'albinisme partial chez la Musaraigne commune. Bull. Soc Zool. France: 134-135. J a ckson, H. H. T., 1928: A taxonomic reviev of the American long-tailed Shrews. N. Am. Fauna, 51: 1-238 + I-VI. J on e s, T. S., 1962: Albinism in an African shrew (Crocidura schweitzeri). Mammalia, 26: 135. M o h r, E., 1931: Die Säugetiere Schleswig-Holsteins. Altona, Elbe: $1-136$. M urray, L. T., 1939: An albino Blarina from Indiana. J. Mamm., 20: 501. P e a r c e, J., 1934: Albinism in the cinereus Shrew. Ib., 15: 67. S a int-Giro n s, M. C., 1963: Notes faunistiques sur les Mammifères de la région de Besse-en-Chandesse (Ruyde-Dôme) Rev. Sci. nat d'Auvergne, 27: 1-14. S ély s - L o n g s c h a m p s, E., de, 1839: Etude de micromammalogie, Revue des Musaraignes, des Rats et des Campagnols. Roret: 1-165. Paris. S h a piro, J., 1950: Notes on population dynamics of Microtus and Blarina with a record of albinism in Blarina. J. Wildlife Mgmt. 14: 359-360. S im e, P. R., 1940: Albino short-tailed shrew from Connecticut. J. Mamm., 21: 214. Ulmer, F. A., jr., 1940 a: Albinism in Blarina. J. Mamm., 21: 89. U $1 \mathrm{~m}$ e r, F. A., jr. 1940 b: A Delavare record of albinism in Blarina. J. Mamm., 21: 457. W ill i a m s, M. W., 1962: An albino short-tailed shrew from Vermont. J. Mamm., 43: 424-425.

Mammals Research Institute, Polish Academy of Sciences, Białowieża.

\section{Zolo PESHEV}

IS SOREX CAECUTIENS LAX M A N, 1788 TO BE FOUND IN BULGARIA?

CZY ZOSTAE ZNALEZIONY W BUŁGARII SOREX CAECUTIENS LA X M A N N, 1788?

In $1951 \mathrm{M}$ a rkov in a short note reported the existence of Sorex macropygmaeus Miller, 1901 (= S. caecutiens Laxmann, 1788) in Bulgaria. The five specimens which gave rise to this information were caught on the Moussala Ridge in the Rila Mts. near the Maritsa Forester's Lodge. 